\title{
KONSEKUENSI YANG TIMBUL DARI ASAS LEGALITAS DALAM HUKUM PIDANA MATERIIL
}

\author{
Endang Pristiwati \\ Fakultas Syariah dan Ekonomi Islam IAIN Antasari, Jl. Jenderal Ahmad Yani Km 4,5 Banjarmasin \\ e-mail: pristiwati.endang@gmail.com
}

\begin{abstract}
The principle of legitimacy as a state aims to protect the society, which is expressed in the principle of legality. While the purpose of the law is more fundamental justice. This principle is officially defined as what is just stated by the constitution. This definition however has been left by some developed countries which is according to them could not be extended in its application. Therefore the definition of the principle of legitimacy should be expanded comprehensively in order reach wider consequence in the law and constitution. Substantive legality principle holds that the main purpose of the law is that justice can be realized based on the laws that have a broader scope than just the law, so it should have been in Indonesia also have to switch the view of the use of formal legality principle to the principle of legality material.
\end{abstract}

Abstrak: Salah satu tujuan hukum adalah menjamin kepastian hukum, yang dinyatakan dalam asas legalitas (legalitas formil). Sedangkan tujuan hukum yang lain yang lebih mendasar adalah mewujudkan keadilan. Asas legalitas formil ini memang dapat memberikan kepastian hukum, namun kurang memberikan keadilan karena asas legalitas formil hanya mengacu pada bunyi undang-undang saja. Dewasa ini asas ini mulai ditinggalkan oleh sebagian besar Negara-negara di dunia, yang beralih pada asas legalitas materiil. Asas legalitas materiil ini berpandangan bahwa tujuan utama dari hukum adalah mewujudkan keadilan yang mana hal itu hanya bisa diwujudkan jika berpedoman pada hukum yang mempunyai cakupan lebih luas dibanding hanya undang-undang saja, sehingga sudah saatnya di Indonesiapun juga harus beralih pandangan dari penggunaan asas legalitas formil ke asas legalitas materiil.

Kata kunci: Asas legalitas, bukum pidana, legalitas

\section{Pendahuluan}

Pada bagian akhir suatu peraturan perundangundangan selalu ditemukan ketentuan yang menyatakan bahwa:'Peraturan perundangundangan ini berlaku sejak saat diundangkan". Hal tersebut berarti bahwa peraturan prundangundangan pada dasarnya berlaku untuk masa yang akan datang setelah suatu peraturan itu dibuat.

Prinsip berlakunya hukum pidana menurut waktu ini terdapat dalam Pasal 1 ayat (1) Kitab Undang-Undang Hukum Pidana, yang berbunyi: "Tiada suatu perbuatan boleh dihukum, melainkan atas kekuatan ketentuan pidana dalam undang-undang, yang ada terdahulu dari pada perbuatan itu".

Di dalam hukum pidana, prinsip tersebut dikenal dengan "asas legalitas" atau "principle of legality", merupakan suatu asas yang sangat fundamental dalam Hukum Pidana karena merupakan bentuk perlindungan terhadap individu terutama pelaku tindak pidana dalam menjamin keadilan dan kepastian hukum
Asas legalitas ini dirumuskan dalam bahasa Latin:"Nullum delictum, nulla poena, sine praevia lege poenali", 1 yang artinya bahwa suatu perbuatan tidak dapat dipidana, kecuali berdasarkan kekuatan ketentuan perundang-undangan pidana yang telah ada sebelumnya.

Asas legalitas ini telah berlaku di berbagai negara yang menggunakan hukum pidana yang telah dikodifikasi dalam suatu "wetboek" seperti negara-negara yang menganut system hukum Eropa Kontinental. Asas ini juga termuat dalam Deklarasi Universal Hak-hak Asasi Manusia 1948 (Pasal 11). ${ }^{2}$

Yang menjadi pertanyaan adalah: mengapa asas legalitas ini diperlukan dan apa konsekuensi dari diberlakukannya asas ini?

\footnotetext{
1 Sudarto, Hukum Pidana I, Yayasan Sudarto, Fak. Hukum UNDIP Semarang, 1990, hlm. 22.

2 Adami Chazawi, Pelajaran Hukum Pidana, Raja Grafindo Persada, Jakarta, 2007, hlm. 170.
} 


\section{Sejarah Timbulnya Asas Legalitas}

Asas legalitas ini bermula dari Eropa Barat, pada abad XVIII dimana pada waktu itu para ahli hukum berjuang melawan rezim monarki absolute. Pada masa rezim ini hukum pidana dijalankan secara sewenang-wenang, perbuatan pidana ditentukan oleh raja sebagai simbul kekuasaan. Hak-hak warga negara tidak dihormati, hak asasi ditekan dan belum tenta. seseorang dapat menuntut lewat peradilan bebas. Hal ini dikarenakan hukum pidana yang dipakai pada waktu itu adalah hukum Romawi yang menganut system "Criminal Extra Ordonaria" artinya kejahatan yang tidak disebut dalam undang-undang. Sistem ini dalam menentukan suatu tindak pidana tidak didasarkan pada suatu peraturan perundang-undangan, melainkan berdasar pada kehendak dan kepentingan raja sebagai pengasa yang tidak terbatas.

Dari situlah timbul pemikiran tentang harus ditentukannya peraturan terlebih dahulu tentang perbuatan yang dilarang, dimaksudkan agar penduduk mengetahui perbuatan yang dibolehkan dan yang dilarang. Asas legalitas ini pertama kali ditemukan dalam bukunya Montesquieu yang berjudul "L'esprit des Lois" 1748 dan buku tulisan Rousseau yang berjudul "Dus Contract Social". ${ }^{3}$

Montesuieu merupakan salah seorang ahli hukum yang memperjuangkan asas legalitas ini, dengan teori "Trias Politica" nya. Teori ini mengajarkan adanya pemisahan yang jelas pada masing-masing kekuasaan yakni:

1. Kekuasaan legislatif atau kekuasaan membuat undang-undang yang dipegang oleh parlemen;

2. Kekuasaan eksekutif dipegang pemerintah;

3. Kekuasaan yudikatif yang dipegang badan kehakiman.

Dengan system sparation of power tersebut Montesquieu berpendapat bahwa diluar undangundang tidak ada hukum. Undang-undang dibuat oleh DPR, dilaksanakan oleh raja, dan hakim yang bertugas mengadili perkara-perkara yang timbul sebagai akibat adanya pelanggaran terhadap aturan undang-undang. Dipisahkannya masing-masing kekuasaan tersebut dimaksudkan untuk membatasi kekuasaan raja yang absolut. Kekuasaan yang berada pada satu tangan akan menimbulkan kesewenang-wengan penguasa.

Jadi parlemen yang bertugas sebagai pembuat suatu peraturan ini yang menentukan perbuatan apa yang dapat dianggap sebagai tindak pidana dan bagaimana cara menjatuhkan pidana. Untuk dapat dikatakan sebagai perbuatan pidana haruslah dirumuskan terlebih dahulu dalam suatu peraturan perundang-undangan.

Jean Jaques Rousseau mempunyai pendapat yang sama dengan Montequieu, dia mengemukakan pendapatnya mengenai:

Contrac Soaial atau perjanjian masyarakat, bahwa negara terbentuk karena adanya perjanjian masyarakat, di dalam negara modern rakyatlah yang memegang kekuasaan.

Maksudnya adalah hukum dibuat oleh masyarakat dalam bentuk undang-undang, pemerintah sebagai badan eksekutif pelaksana undangundang, dan hakim sebagai badan yudikatif. Kedua badan tersebut tidak dibolehkan membentuk undang-undang, hakim hanya boleh menggunakan hukum dan tidak boleh membuat hukum.

Asas legalitas ini dipakai dalam bentuk undang-undang pada saat pecahnya revolusi Perancis yang dinyatakan dalam Pasal 8 "Declaration des droits de L'bomme et du citoyen"1789, yang bunyinya: Tidak ada sesuatu yang boleh dipidana selain karena suatu wet yang ditetapkan dalam undang-undang dan diundangkan secara $\operatorname{sah}^{4}$.

Perjuangan Montesquieu ini kemudian dilanjutkan oleh Anselm Von Feuerbah yang mengemukakan dalam bahasa Latin dalam bukunya yang berjudul "Lebrbuch des Peinlichen Reche" tahun 1801, yaitu "Nullum delictum nulla poena sine praevia lege", yang artinya tidak ada tindak pidana dan tidak ada pidana tanpa adanya ketentuan hukum terlebih dahulu yang menentukan ${ }^{5}$.

Kemudian dibawah pemerintahan Napoleon 1801 asas tersebut dimasukkan dalam Code Penal Perancis tepatnya terdapat dalam Pasal 4. Belanda sebagai Negara jajahan Perancis diberlakukan pula asas tersebut dalam $W$ etboek van Strafrecht Nederland 1881 yang terletak dalam Pasal 1. Demikian halnya Hindia Belanda (Indonesia) sebagai negara jajahan Belanda menggunakan pula Wetboek van Strafrecht voor Nederland Indie 1918. Setelah Indonesia merdekapun masih menggunakan WvS tersebut meski telah mengalami beberapa perubahan tepatnya terdapat pada Pasal 1 ayat (1) KUHP. Moelyatno, Asas- Asas Hukum Pidana, Rineka Cipta,
Jakarta 1993, hlm. 24.

\footnotetext{
5 Ibid, hlm. 23
} 
Asas legalitas ini mengandung tiga unsur yang bersifat hakiki, yaitu:

1. Hukum pidana yang berlaku harus berbentuk tertulis;

2. Perundang-undangan pidana tidak boleh berlaku surut dan;

3. Tidak diperbolehkan menggunakan analogi.

Untuk menjamin kepastian hukum maka peraturan perundang-undangan yang berlaku harus berbentuk tertulis. Hukum yang berlaku hanyalah undang-undang, di luar undang-undang tertulis bukan merupakan suatu hukum. Dengan bentuknya yang tertulis ini memudahkan hakim dalam memeriksa dan memutus suatu perkara, karena hakim hanya menerima perkara yang sudah jelas hukumnya, tidak usah repot-repot mencari hukum apa yang akan diberlakuka karena sudah tersedia.

\section{Konsekuensi Yang Timbul Dari Berlakunya Asas Legalitas Materiil}

Dipergunakannya asas legalitas formal ini, menimbulkan konsekuensi pada hakim, dimana hakim dalam menjatuhkan putusannya senantiasa terikat pada undang-undang. Hakim tidak mempunyai kebebasan dalam menafsirkan hukum sementara dalam pasal $20 \mathrm{AB}$ disebutkan bahwa hakim harus mengadili berdasarkan undangundang.

Asas ini disatu pihak ada keuntungannya bagi kepentingan pribadi, namun sebagai konsekuensi dengan adanya asas legalitas ini adalah asas nullum delictum kurang melindungi kepentingan kepentingan kolektif (collective bealngen), karena asas ini menggambarkan yang dapat dihukum adalah mereka yang melakukan suatu perbuatan yang oleh hukum (peraturan yang telah ada) disebut secara tegas sebagai pelanggaran ketertiban umum. Disamping itu, asas legalitas ini akan menjadi halangan bagi hakim untuk menghukum seseorang yang telah melakukan suatu perbuatan pidana, namun dalam undang-undang perbuatan tersebut belum diatur.

Tidak sempurnanya pelaksanaan hukum pidana selama ini dalam praktek peradilan masih dapat diatasi, yakni dengan memberikan wewenang kepada hakim dalam penerapan hukum pidana adat atas perbuatan-perbuatan yang terlarang. Perbuatan-perbuatan yang demikian itu tidak atau belum diancam dengan Kitab Undang-Undang Hukum Pidana.

Apabila dikaji lebih mendalam, dapat dilihat bahwa asas legalitas ini mengandung banyak kerugiannya, namun yang menjadi pertanyaan adalah mengapa asas ini masih saja berlaku di Indonesia, sedangkan di Negara-negara lain seperti pada Unisovyet (sebelum bubar), asas ini sudah ditinggalkan. Untuk menjawab pertanyaan tersebut kita harus melihat kembali mengenai sejarah lahirnya asas legalitas. Seperti kita ketahui bahwa asas ini lahir pada suatu jaman yang saat itu merupakan puncak perkembangan terhadap anggapan individualitas terhadap hukum, dan hukum yang memberikan jaminan penuh bagi kemerdekaan diri pribadi dan saat itu pandangan hukum sangat individualistis, sehingga sudah barang tentu asas nullum delictum ini dipertahankan.

Indonesia merupakan negara yang menggunakan hukum pidana warisan produk kolonial yang pada saat itu berfaham individualitas, dimana sampai sekarang masih tetap menggunakan KUHP kolonial yang baru. Dengan masih berlakunya asas legalitas, maka sangat berpengaruh terhadap keberadaan dan perkembangan hukum di Indonesia, terutama dalam hubungannya dengan hukum adat yang ada. Indonesia merupakan negara dengan adat budaya yang sangat beragam, namun konsekuensi terhadap hukum adat adalah meskipun dalam hukum adat suatu perbuatan adalah dilarang, tetap saja tidak dapat dipidana, karena peraturannya yang berbentuk tidak tertulis. Ini sebagai konsekuensi dari diberlakukannya asas legalitas yang mensyaratkan bahwa hanya hukum tertulis yang dapat menjadi dasar bagi penjatuhan pidana.

Dengan demikian kita dapat melihat bahwa asas legalitas ini mempunyai kekurangan yakni bersifat kaku, kurang dinamis, sedangkan masyarakat maupun tekknologi berkembang begitu cepat. Sehingga hukum yang ada tidak dapat mengakomodir tuntutan masyarakat, selalu berjalan ditempat dan ketinggalan jaman. Padahal jika kita melihat aturan-aturan lain yang tersebar di luar KUHP ternyata masih ada aturan yang memberikan ruang terhadap hukum adat sebagai dasar bagi suatu hukuman yang akan dijatuhkan terhadap pelaku tindak pidana. Dalam Undangundang Dasar Sementara 1950 misalnya, disebutkan dalam Pasal 14 ayat (2) bahwa: "Tidak seorang juapun boleh dituntut untuk dihukum atau dijatuhi hukuman kecuali karena suatu aturan bukum yang ada dan berlaku terhadapnya".

Dalam pasal tersebut dipakai istilah "aturan bukum" (Rect) yang pengertiannya lebih luas dari pada aturan "undang-undang" (WET), karena 
dapat berbentuk "hukum tertulis" maupun "hukum tidak tertulis". ${ }^{6}$

Dari bunyi pasal tersebut dapat dilihat bahwa hukum pidana adat mempunyai dasar yang kuat untuk dijadikan dasar hukum dalam menjatuhkan pidana.

Selain itu ada pula aturan-aturan hukum masih memberikan ruang terhadap berlakunya hukum pidana adat yakni aturan yang terdapat pada Pasal 5 ayat (3) sub b Undang-Undang Darurat No. 1 Drt. 1951 yang berbunyi:

“... bahwa suatu perbuatan yang menurut hukum yang hidup harus dianggap perbuatan pidana, akan tetapi tiada bandingnya dalam Kitab Hukum Pidana Sipil, maka dianggap diancam dengan hukuman yang tidak boleh lebih dari tiga bulan penjara atau denda lima ratus rupiah. Yaitu sebagai hukuman pengganti bilamana hukuman adat yang dijatuhkan tidak diikuti oleh pihak terhukum dan penggantian yang dimaksud dianggap sepadan oleh hakim dengan besar kesalahan si terhukum.........Bahwa bilamana hukuman adat yang dijatuhkan itu menurut pikiran hakim melampaui hukuman kurungan atau denda yang dimaksud di atas, maka ......terdakwa dapat dikenakan hukuman pengganti setinggi 10 tahun penjara, dengan pengertian bahwa hukuman adat yang...... tidak selaras lagi dengan zaman senantiasa diganti seperti tersebut diatas".

Dari bunyi ketentuan Pasal 5 ayat (3) sub b UU No.1 Drt tahun 1951 tersebut dapat diambil kesimpulan bahwa hukum pidana adat hanya berlaku untuk sementara saja yaitu bagi kaulakaula atau orang-orang yang dahulu diadili di daerah swapraja/pengadilan adat. Di dalam penjelasan undang-undang tersebut menerangkan bahwa masih dipertahankannya hukum pidana adat oleh karena dalam tempo dulu yang pendek Kitab Undang-Undang Hukum Pidana Sipil dan diulang pengundangannya setelah kitab ini disesuaikan dengan keadaan pemerintah yang baru ini dan belum tentu apakah perbuatanperbuatan pidana adat harus diakui terus: maka untuk sementara waktu perbuatan-perbuatan pidana adat ini dan hukuman-hukuman adat dihapus.

Sebagai tindakan peralihan, maka ketentuan tersebut untuk selanjutnya diadakan peraturan untuk menyebarkan hukuman-hukuman adat itu,

6 Barda Nawawi Arief, Bunga Rampai bukum Pidana, Citra Aditya Bakti, Bandung, 1996, hlm. 91. dalam hal mana diadakan perbedaan diantara perbuatan-perbuatan pidana adat yang tidak ada bandingnya dengan Kitab Undang-Undang Hukum Pidana Sipil dan perbuatan-perbuatan pidana adat yang ada bandingnya dalam Kitab Undang-Undang Pidana Sipil.

Ketentuan Pasal 5 ayat (3) sub b, bila dihubungkan dengan ketentuan Pasal 1 ayat (1) Kitab Undang-Undang Hukum Pidana ditemukan adanya pergeseran prinsip yang dianut oleh hukum pidana Indonesia. Pengertian materiil adanya perbuatan itu tidak saja dilarang oleh undang-undang (hukum tertulis) tetapi jua oleh aturan-aturan yang tidak tertulis. Walaupun di dalam undang-undang belum ada dan tidak mengancam pidana atas perbuatan itu, tetapi hukum tidak tertulis menganggap perbuatan itu sebagai perbuatan tercela maka tidak ada alasan bagi hakim untuk tidak mejatuhkan pidana atas dilakukannya perbuatan tersebut.

Disamping itu Undang-Undang Kekuasaan Kehakiman (UU No. 14 tahun 1970) menetapkan:

a. Pasal 14 ayat (1): "Pengadilan tidak boleh menolak untuk memeriksa suatu perkara yang diajukan dengan dalih bahwa hukum tidak/kurang jelas, melainkan wajib untuk memeriksa dan mengadilinya".

b. Pasal 23 ayat (1): "Segala putusan pengadilan selain harus menurut alasan-alasan dan dasardasar putusan itu, juga harus memuat pula pasal-pasal tertentu dari peraturan-peraturan yang bersangkutan atau sumber hukum tidak tertulis".

c. Pasal 27 ayat (1): "Hakim sebagai penegak hukum dan keadilan wajib menggali, mengikuti dan memahami nilai-nilai hukum yang hidup".

Dari ketentuan pasal-pasal tersebut, maka jelaslah bahwa hukum pidana adat atau hukum tidak tertulis masih dapat dijadikan sebagai landasan untuk menentukan suatu hukum. Hal ini sangat diperlukan di Indonesia mengingat banyaknya adat istiadat yang terdapat di negeri ini dengan hukum pidananya masing-masing. Menurut Van Vollen Hoven di Indonesia terdapat 19 macam masyarakat hukum adat. ${ }^{7}$ Apabila ketentuan-ketentuan tersebut dapat diterapkan dalam pelaksanaan hukum, maka hal ini akan memberikan nilai-nilai keadilan di masyarakat akan tetap tercipta dan terpelihara.

Soeroso, Pengantar Ilmu Hukum, Sinar Grafika, Jakarta, 2008, hlm. 78. 
Namun apakah hal itu dapat dilakukan dengan mudah, serta bagaimana dengan kepastian hukumnya. Untuk itu maka harus dicari jalan keluar agar kepastian hukum dapat tercipta, dan di lain pihak nilai keadilan tetap terpelihara. ${ }^{8}$

Sampai saat ini Indonesia masih tetap menggunakan KUHP warisan kolonial, meski begitu kita masih berupaya untuk menyempurnakan KUHP produk bangsa Indonesia yang baru, mengingat Pasal 1 ayat(1) ini merupakan persoalan paling mendasar, dan apakah asas legalitas sebagaimana yang disebutkan dalam pasal tersebut masih akan dipertahankan.

\section{Asas Legalitas Menurut Konsep KUHP Baru}

Asas legalitas formal dalam KUHP Indonesia saat ini disamping terdapat sudut keuntungannya ada pula sudut kerugiannya. Kelemahan dari berlakunya asas legalitas antara lain:

1. Hukum tidak dapat mengakomodir rasa keadilan yang dituntut masyarakat

2. Undang-undang yang dibentuk selalu ketinggalan jaman, karena tidak dapat mengikuti laju perkembangan jaman dan teknologi yang berkembang begitu cepat;

3. Undang-undang tidak selalu dapat menyelesaikan segala persoalan masyarakat yang timbul.

4. Undang-undang tidak dapat sempurna, karena kadang-kadang menggunakan istilah yang tidak jelas/kabur, sehingga hakim perlu memberikan penafsira.

5. Undang-undang tidak dapat mengatur seluruh aspek kehidupan dalam masyarakat, sehingga memungkinkan terjadi kekosongan hukum. ${ }^{9}$

Namun dibalik semua itu pertanyaan yang timbul adalah bagaimana penyusun konsep KUHP baru dalam merumuskan asas legalitas, apakah masih dicantumkan atau tidak.

Untuk menjawab pertanyaan itu, maka dapat dilihat dan diketahui dari pasal yang bersangkutan, yaitu Pasal 1 ayat (1) konsep KUHP yang bertolak dari asas legalitas dalam pengertian yang formal, bahwa sumber hukum yang utama adalah undang-undang (hukum tertulis). Dengan demikian konsep KUHP barupun masih memuat aadanya asas legalitas ini. Namun konsep KUHP ini memperluas perumusan secara material

8 Mardjono Reksodipuro, Bunga Rampai Permasalaban Dalam Sistem Peradilan Pidana, Pusat Pelayanan Keadilan dan Pengabdian Hukum UI, Jakarta, 1987.

9 Soeroso, loc cit, hlm .90. dengan menegaskan Pasal 1 (1) tersebut tidak mengurangi barlakunya "hukum yang hidup" di dalam masyarakat, yaitu terhadap delik-delik yang tidak ada bandingnya atau tidak telah diatur dalam undang-undang. ${ }^{10}$

Dikatakan oleh Barda Nawawi Arief, salah seorang anggota team perumus KUHP baru bahwa:"Dengan bertolak dari kebijakan perundang-undangan nasional yang ada selama ini seperti ditulis terdahulu, (UU No.1/ Drt/1951 dan UU No. 14 tahun 1970), dapat dikatakan bahwa perluasan asas legalitas secara material di dalam konsep KUHP baru bukanlah merupakan ide yang baru, melainkan hanya melanjutkan dan mengimplementasikan gagasan yang sudah ada. ${ }^{11}$

Perluasan perumusan asas legalitas secara materiil adapat dicarikan dasar pembenarannya pada empat landasan yakni:

1. Landasan kebijakan legislatif nasional yang keluar setelah kemerdekaan antara lain UU No.1 Drt tahun 1951 dan UU No. 14 tahun 1970;

2. Landasan kesepakatan ilmiah dalam seminarseminar nasional ;

3. Landasan sosiologis yang bertolak dari budaya hukum kekeluargaan (menurut Satjipto Rahardjo: budaya hukum perorangan menghasilkan konsep "legisme liberal" dan "konsep rule of law", sedangkan budaya hukum kekeluargaan menghasilkan "legisme kekeluargaan" dan konsep "the rule of justice (moral');

4. Landasan Internasional yang bertolak dari Pasal 15 ICCPR (International Covenant on Civil and Political Rigthts) yang menyebutkan adanya dua dasar/sumber hukum untuk menyetakan dapat dipidananya si pembuat, yaitu:

a. Berdasarkan undang-undang atau hukum positif yang berlaku (ayat 1)

b. Berdasarkan asas-asas atau prinsip hukum umum yang diakui masyarakat bangsabangsa (the general principle of recognized by the commubity of nations, ayat 2).

Dengan tetap dimuatnya asas legalitas ini, maka kepastian hukum masih tetap dipertahankan, oleh karena asas ini disamping mempunyai sifat perlindungan terhadap hukum pidana juga

10 Barda Nawawi Arief, Bunga Rampai Hukum Pidana, Citra Aditya Bakti, Bandung 1996, hlm. 88.

11 Barda Nawawi Arief, Bunga Rampai Hukum Pidana, Citra Aditya Bakti, Bandung, 1996 hlm. 90. 
memberi kekuasaan kepada pemerintah sebagai fungsi instrument, juga dapat menjamin nilai nilai dalam masyarakat tetap terpelihara. Dengan dicantumkannya kedua landasan hukum tersebut, maka akan terciptalah keseimbangan diantara keduanya. Dengan demikian maka asas legalitas ini bersifat materiil dan dapat dikatakan sebagai asas legalitas materiil.

Dengan diterapkannya asas legalitas materiil dalam konsep KUHP baru, maka akan membawa konsekuensi-konsekuensi baik terhadap hukumnya sendiri maupun terhadap pelaksananya (hakim). Konsekuensi terhadap hukumnya sendiri adalah bahwa dengan diterapkannya asas legalitas materiil tersebut maka hukum yang hidup dalam masyarakat akan tetap terpelihara. Sedangkan terhadap masyarakat sendiri, dapat merasakan keadilan yang sebenarnya. Dengan demikian akan terjalin suatu keseimbangan antara hukum positif dengan nilai-nilai yang hidup dalam masyarakat.

Bagi hakim sendiri selaku penegak hukum, diberi kesempatan seluas-luasnya untuk menggali nilai-nilai hukum yang terdapat dalam masyarakat, dengan demikian hakim harus cakap dan selalu berusaha untuk memahami dan mempelajari hukum adat dalam menjalankan tugasnya.

Karena itu dalam sisitem hukum adat jika terhadap suatu persoalan yang belum terdapat aturan hukumnya hakim berwenang bahkan wajib memberikan putusan yang mencerminkan keadilan masyarakat yang tumbuh dan diakui saat ini. Pada saat itu hakim wajib mewujudkan secara konkrit meluli putusannya, apa yang dianggapnya sesuai dengan perasaan hukum masyarakat. Menjadi penting pengetahuan hakim menggali hukum yang hidup dalam masyarakat, dimana sedang terjadi suatu persoalan, karena pengetahuan hakim releven dengan mutu putusan pengadilan yang dihasilkan. Jika pengetahuan hakim terhadap hukum adat kurang memadahi, maka putusan yang dihasilkannyapun tidak akan mencerminkan tuntutan dalam masyarakat.

\section{Kesimpulan}

Asas legalitas merupakan asas yang fundamental dalam hukum pidana. Sampai saat ini
Hukum Pidana Indonesia menggunakan Asas legalitas formil, yang ternyata mengandung banyak kekurangan, sedangkan untuk dapat mewujudkan keadilan dalam masyarakat dimana hukum itu diberlakukan diperlukan asas legalitas yang seimbang antara kepastian hukum dan keadilan namun jika keduanya tidak memungkinkan untuk berjalan beriringan, maka nilai keadilanlah yang perlu dikedepankan, sehingga yang diperlukan adalah rumusan asas legalitas materiil sebagaimana dimuat dalam Konsep KUHP Baru.

\section{Daftar Rujukan}

Arief, Barda Nawawi, Perbandingan Hukum Pidana, Raja Grafindo Persada, Jakarta, 2006.

Arif, Barda Nawawi, Bunga Rampai Hukum Pidana, Citra Aditya Bakti, Jakarta, 1996.

Chazawi, Adami, Pelajaran Hukum Pidana, Raja Grafindo Persada, Jakarta, 2007.

Djamali, Abdoel, Pengantar Ilmu Hukum, Raja Grafindo Persada, Jakarta, 2005

Dirdjosisworo, Soedjono, Pengantar Ilmu Hukum, Raja Grafindo Persada, Jakarta, 2005.

Moeljatno, Asas-Asas Hukum Pidana, Rineka Cipta, Jakarta, 1993.

Moeljatno, Kitab Undang-Undang Hukum Pidana, tanpa tahun

Muladi, Hak Asasi Manusia, Politik dan Sistem Peradilan Pidana, Badan Penerbit UNDIP, Semarang, 1997.

Reksodipuro, Mardjono, Bunga Rampai Permasalaban Dalam Sistem Peradilan pidana, PusatPelayanan Keadilan dan Pengabdian Hukum UI, Jakarta, 1987.

Sudarto, Hukum Pidana I, Yayasan Sudarto, Fakultas Hukum UNDIP, Semarang, 1990

Sudarto, Hukum dan Hukum Pidana, Alumni, Bandung, 1986.

Soeroso, Pengantar Ilmu Hukum, Sinar Grafika, Jakarta, 2008.

Sumitro, Ronny Hanitijo, Perspektif Sosial dalam Pemahaman Masalab-Masalab Hukum, Agung Press, Semarang, 1989.

Soesilo, Kitab Unsang-Undang Hukum Pidana, Politea, Bogor, 1988.

Utrecht, E, Hukum Pidana I, Pustaka Tinta Mas, Surabaya, 1986

Kitab Undang-Undang Hukum Pidana. 